\title{
KRITIK KHALED ABOU EL-FADL ATAS EPISTEMOLOGI HADITS SUJUD PADA SUAMI
}

\author{
M. Rifian Panigoro, MA \\ Dosen Fakultas Ushuluddin dan Dakwah \\ IAIN Sultan Amai Gorontalo \\ E-mail: m.rifianpanigoro@gmail.com
}

\begin{abstract}
Abstrak
Khaled M. Abou El Fadl seorang intelektual muslim yang dikenal luas sebagai penulis prolific. Ia mengkritik studi hadis kaum puritan yaitu studi hadist yang dilakukan oleh ulama tradisional yang berkisar pada kritik sanad dan kritik matan, salah satunya adalah hadist mengenai istri yang sujud kepada suami. Menurut Khaled hadist ini seringkali dijadikan acuan oleh beberapa orang untuk melegitimasi hubungan suami istri, disini ia mengutarakan kritik sanad dan matannya. Ia akan membuka pandangan baru kita untuk tidak menggunakan hadîts-hadîts tentang bersujud dan taat kepada suami sebagai sandaran dalam persoalan hukum atau teologi. dengan cara mengevaluasi secara menyeluruh semua hal yang bisa ditemukan dari hadîts-hadits tersebut. Menurutnya hadîts tersebut sangat bertentangan dengan pemahaman dalam teks AlQuran. Dampak nyata dari hadîts tersebut adalah seorang istri mempunyai kewajiban yang sangat besar terhadap lakilaki yang menjadi suaminya, semata karena posisi laki-laki tersebut sebagai suaminya. Seorang suami berhak mendapat penghormatan dan pelayanan dari istrinya. Hadits ini akan terkesan merendahkan perempuan apabila dipahami secara literal. Sehingga Hadîts ini membutuhkan riwayat-riwayat lain untuk menjelaskan makna yang terkandung di dalamnya.
\end{abstract}

\section{Kata Kunci: Khaled Abou El Fad1, Hadist Sujud Pada Suami, Kritik Matan.}

\section{Abstract}

Khaled M. Abou El Fadl, a Muslim intellectual widely known as prolific writer. He criticized the study of puritan hadith, namely the study of hadiths carried out by traditional scholars who revolved around criticizing sanad and matan criticism, one of which was the hadith concerning the wife who prostrated to the husband. According to Khaled, this hadith is often used as a reference by some people to legitimize husband and wife relations, here he expressed his criticism of the sanad and his matan. He will open our new view not to use the hadiths of 
M. Rifian Panigoro, MA : Kritik Khaled Abou El-Fadl Atas Epistemologi Hadits Sujud pada Suami

prostration and obedience to the husband as a support for legal or theological matters. by evaluating all things that can be found from the hadits-hadits. According to him the hadits are very contrary to the understanding in the Qur'anic text. The real impact of the hadits is that a wife has a very large obligation on the man who is her husband, simply because of the position of the man as her husband. A husband has the right to receive respect and service from his wife. These hadiths will seem to be degrading to women if they are understood literally. So these Hadiths need other histories to explain the meaning contained in them.

\section{Keywords: Khaled Abou El Fadl, Prostrate Hadith at Husband, Matan's Criticism.}

\section{A. PENDAhULUAN}

Hadist dalam masa kodifikasi mengalami proses yang panjang. Dimana hadist merupakan catatan rekaman para sahabat atas perilaku, tindakan dan persetujuan Nabi yang kemudian rekaman para sahabat tersebut dituturkan secara lisan oleh generasi-generasi sesudahnya hingga akhir didokumentasikan dalam berbagai kitab hadist. Dari sini, bisa kita melihat bahwasanya hadist memiliki kerentatan atas problem otentisitasnya.

Sebab, dalam proses kodifikasi tidak bisa terlepas dari campur tangan manusia dalam penghafalan, periwayatan hingga pemeliharaan dan penulisannya dalam bentuk teks. Sehingga persoalan hadist tidak bisa dinafikan adanya kemungkinan pemalsuan, persoalan daya ingat hingga subjectivitas perawi dalam proses transmisi periwayatannya. ${ }^{31}$ Sebagaimana kontroversinya hadist-hadist misogini, yaitu hadist yang terlalu membela laki-laki atas perempuan.

${ }^{31}$ Khaled M. Abou el-Fadl, Atas Nama Tuhan: dari Fiqih Otorites ke Fiqh Otoritatif, terj R. Cecep Lukman Yasin (Jakarta: Serami Ilmu Semesta, 2004), h. 130. 
Beberapa hadist misogini terkadang secara matan tidak sesuai dengan teks al Qur'an dan akal manusia. Seperti contohnya hadist tentang "sujud ke suami".

Fakta sosial, beberapa orang membuat hadist misogini sebagai landasan hukum dan otoritas tinggi yang kemudian dipegang dan dijadikan pedoman ${ }^{32}$ yang seharusnya hadist tersebut harus dilakukan kritik sanad dan matan terlebih dahulu. Dalam hal ini Khaled memberikan kritikan atas kaum puritan karena menjadikan hadis Nabi sebagai alat legitimasi atas keputusan dan sikap mereka yang semena-mena dan ganjil. Selain berada diluar konteks dan seringkali hadis-hadis yang mereka kutip diragukan autentisitasnya. Akibatnya, mereka sering terjebak dalam sikap puritanisme dan antiintelektualisme.

Khaled merupakan intelektual publik yang terkemuka dalam bidang hukum Islam. Tulisan-tulisan akademisnya dalam bidang agama banyak dilakukan dengan pendekatan nilai-nilai moral dan kemanusiaan. Ia dikenal juga sebagai pembela hak-hak perempuan yang sangat gigih. Saat dikampung halamannya Ia termasuk anggota dalam gerakan puritan Wahabi yang tumbuh subur di lingkungannya. Akan tetapi, keluarganya termasuk terbuka terhadap pemikiran. Mereka menawarkan berbagai khazanah keilmuwan Islam dari berbagai aliran kepadanya yang kemudian mengantarkannya hingga ke Yale University.

Lebih lanjut, Khaled menawarkan konsep kepengarangan hadist untuk mencoba melampaui kritik

32 Fatima Mernissi, Women and Islam: an Historical and Theological Enquiry (Oxford UK and Cambridge USA: Blackwell, 1991), h. 99-101. 
M. Rifian Panigoro, MA : Kritik Khaled Abou El-Fadl Atas Epistemologi Hadits Sujud pada Suami

sanad dan kritik matan dalam studi hadis tradisional dan sekaligus mengeritisi kelompok-kelompok puritan yang menjadikan hadis sebgai alat untuk memenangkan kompetisi melantunkan hadis yang menurut Khaled hanya sebagai retorika merebutkan klaim autentisitas Islam. Oleh sebab itu, apa yang ditawarkan El Fadl tersebut perlu diapresiasi dan dieksplorasi lebih jauh.

\section{B. PEMBahasAN}

\section{Biografi Khaled Abou E1 Fadl}

Nama lengkapnya adalah Khaled Medhat Abou El Fadl. Ia dilahirkan di Kuwait pada tahun 1963. Kedua orang tuanya yang berdarah Mesir. Pendidikan dasar dan menengahnya, ia tamatkan di negeri kelahirannya, Kuwait. Kemudian pendidikannya dilanjutkan di Mesir. Sebagaimana tradisi bangsa Arab yang memegang teguh tradisi hafalan, Abou El Fadl kecil sudah hafal Alquran sejak usia 12 tahun. Ayahnya yang berprofesi sebagai seorang pengacara, sangat menginginkan Abou El Fadl menjadi seorang yang menguasai hukum Islam. Ayahnya sering mengujinya dengan pertanyaanpertanyaan seputar masalah hukum. Setiap liburan musim panas, Abou El Fadl menyempatkan menghadiri kelas-kelas Alquran dan ilmu-ilmu syariat di Masjid Al-Azhar, Kairo, khususnya dalam kelas yang dipimpin oleh Shaykh Muhammad al-Ghazâlî (w. 1995), tokoh pemikir Islam moderat dari barisan revivalis yang ia kagumi. ${ }^{33}$

33 Nasrullah, hermeneutika otoritatif khaled m. Abou el fadl: metode kritik atas penafsiran otoritarianisme dalam pemikiran islam, Jurnal Hunafa Vol. 5, No. 2, Agustus 2008, h. 138. 
Pada tahun 1982, Abou El Fadl meninggalkan Mesir menuju Amerika dan melanjutkan studinya di Yale University dengan mendalami ilmu hukum selama empat tahun dan dinyatakan lulus studi bachelor-nya dengan predikat cumlaude. Tahun 1989, ia menamatkan studi Magister Hukum pada University of Pennsylvania. Atas prestasinya itu, ia diterima mengabdi di Pengadilan Tinggi (Suppreme Court Justice) wilayah Arizona, sebagai pengacara bidang hukum dagang dan hukum imigrasi. Dari sinilah kemudian Abou El Fadl mendapatkan kewarganegaraan Amerika, sekaligus dipercaya sebagai staf pengajar di University of Texas di Austin. Kemudian ia melanjutkan studi doktoralnya di University of Princeton. Pada tahun 1999, Abou El Fadl mendapat gelar Ph.D dalam bidang hukum Islam. Sjak saat hingga sekarang, ia dipercaya menjabat sebagai profesor hukum Islam pada School of Law, University of California, Los Angeles (UCLA). Abou El Fadl adalah penulis yang produktif, dan karena karya-karyanya tersebutlah yang melambungkan namanya dan diperhitungkan dalam blantika diskursus intelektual, baik di Amerika maupun di dunia Islam. Di antara karya-karyanya yang sudah diterbitkan dalam bentuk buku adalah:

"Speaking in God's Name: Islamic Law, Authority and Woman, Rebellion and Violence in Islamic Law, And God Knows the Soldiers: The Authoritative and Authoritarian in Islamic Discourse, The Authoritative and Authoritarian in Islamic Discourses: A Contemporary Case study, Islam and Challenge of Democracy, The Place of Tolerance in Islam, Conference of Books: The Search for Beauty in Islam.

Karya-karyanya di atas pada umumnnya sudah banyak yang diterjemahkan ke bahasa Indonesia. Di samping itu, 
M. Rifian Panigoro, MA : Kritik Khaled Abou El-Fadl Atas Epistemologi Hadits Sujud pada Suami

tentu masih banyak lagi tulisan ilmiah Abou El Fadl yang lain, baik dalam bentuk artikel maupun jurnal ilmiah. ${ }^{34}$

\section{Pemahaman khaled tentang hadits Sujud Pada Suami}

Mengawali komentarnya tentang hadîts sujud pada suami, Khaled mengkritisi mereka yang setuju dengan CRLO kemudian menggunakan ayat al-Qur'an “kaum laki-laki adalah pemimpin bagi kaum perempuan, oleh karena Allah telah melebihkan sebagian mereka atas sebagian yang lain, dan Karena mereka telah menafkahkan sebagian dari harta mereka." 35 Sebagai bukti tambahan bahwa seorang suami berhak menyuruh dan mendisiplinkan istrinya. Kata yang digunakan dalam ayat tersebut, qawwâmûn, bisa berarti pelindung, pemelihara, penjaga, atau bahkan pelayan. Kata yang sama digunakan dalam al-Qur'an pada konteks yang berbeda, yaitu ketika orang-orang Islam diperintahkan untuk menjadi qawwâmûn keadilan. ${ }^{36}$

Meskipun demikian diskursus al-Qur'an tidak memainkan peran utama dalam penetapan-penetapan tentang ketaatan salah satu pasangan. Menurut Khaled Peran tersebut dimainkan oleh hadîts yang dinisbatan kepada Nabi diantaranya ialah hadits yang menyatakan bahwa Nabi pernah bersabda:"Seseorang tidak dibenarkan untuk sujud pada siapapun. Tapi sekiranya saya harus menyuruh seseorang untuk bersujud kepada seseorang lainnya, saya akan menyuruh seorang istri bersujud kepada suaminya karena

34 Nasrullah, hermeneutika otoritatif khaled m. Abou el fadl: metode kritik atas penafsiran otoritarianisme dalam pemikiran islam, h. 140

35 Khaled Abou el-Fadl, Speaking in God's Name, (Oxford: Oneworld Publications, 2001), h. 215-216.

36 Khaled Abou el-Fadl, Speaking in God's Name,h, 217. 
begitu besarnya hak suami pada istrinya." 37 hadits tersebut diriwayatkan dalam berbagai versi dan melalui berbagai rantai periwayatan oleh Abû Dâwûd, al-Tirmidzî, Ibnu Mâjah, Ahmad ibn Hanbal dalam musnadnya, an-Nasâ'î, dan Ibn Hibbân.

Versi lainnya dari hadîts tersebut ialah dari Mahmûd ibn Ghaylân meriwayatkan bahwa Abû Hurairah mengatakan bahwa Nabi pernah menegaskan: "jika saya harus menyuruh seseorang untuk bersujud kepada orang lain, saya akan menyuruh seorang istri bersujud kepada suaminya." 38

Versi ini juga diriwayatkan oleh Fadhl ibn Jubayr dari Abû Umâmah al-Bahlî. Dalam versi lainnya Abû Bakr ibn Abî Syaybah meriwayatkan bahwa ' $A$ 'isyah mengatakan bahwa Nabi pernah bersabda: "jika saya harus menyuruh seseorang untuk bersujud kepada orang lain saya akan menyuruh seorang istri bersujud kepada suaminya. Jika seorang suami menyuruh istrinya untuk mengubah gunung yang berwarna merah menjadi gunung berwarna hitam dan dari gunung hitam menjadi gunung merah, maka ia wajib mematuhi perintah tersebut. ${ }^{39}$

Dalam versi lainnya, 'A'isyah diriwayatkan pernah berkata bahwa Nabi sedang duduk bersama para sahabatnya dari golongan Muhâjirûn dan Anshâr ketika seekor unta datang

37 Abû Muhammad Abdillâh bin Abdirrahmân bin Fadhil bin Bahram al-Tamîmî al-Dârimî as-Samarqandi, Sunan al-Dârimi, Kitâb ash-Shalâh, Bab Larangan untuk Bersujud Kepada Orang Lain, (Beirût: Dâr al-Kutub al-Ilmiyah, 1996), No. 1470. Juz I, h. 341.

38 Abû 'îsâ Muhammad bin Sûrah al-Tirmidzî, Sunan Tirmidzy, Kitab ar-Radhâ', Bab Hak-hak Suami atas Istri, (Beirût: Dâr al-Fikr, 1994), No. 1155, Juz, IV, h. 253..

39 Abû 'Abdillah Muhammad bin Yazîd ar-Rab'î al-Quzwainî Ibnu Mâjah, Sunan Ibnu Mâjah, Kitâb an-Nikâh, Bab Hak Suami atas Istri, (Beirût: Dâr ihyâ' at-Turâts al-'Arabî, tth), No. 1906, Juz, I, h. 595. 
M. Rifian Panigoro, MA : Kritik Khaled Abou El-Fadl Atas Epistemologi Hadits Sujud pada Suami

dan berlutut di depan Nabi. Para sahabat berkata, "wahai Nabi, binatang dan pepohonan sujud kepadamu. Bukankah kami lebih berhak melakukannya? Kemudian Nabi berkata, "sembahlah Tuhanmu dan hormati saudaramu..." namun hadîts itu berlanjut dengan pernyataan sebagaimana di atas. 40

Versi lainnya berasal dari Azhar ibn Marwân. Ia meriwayatkan bahwa ketika $\mathrm{Mu}$ ‘âdz kembali dari Syâm, ia bersujud kepada Nabi. Nabi berkata, “apa yang sedang kamu lakukan, Mu'âdz?” Mu'âdz menjawab, “saya baru datang dari Syâm dan saya melihat penduduk di sana bersujud pada pendeta dan orang-orang suci, dan saya juga ingin melakukan hal yang sama kepadamu." Nabi berkata, “jika saya harus menyuruh seseorang untuk bersujud kepada selain Allah, saya akan menyuruh seorang istri bersujud kepada suaminya. Demi Allah, seorang istri belum dipandang telah memenuhi kewajibannya kepada Allah hingga ia memenuhi kewajibannya kepada suaminya, dan jika ia diminta melayani suaminya ketika ia berada di atas unta maka ia tidak boleh menolak permintaan suaminya."41

Versi lainnya adalah tentang Mu'âdz yang kembali dari Yaman, bukan dari Syâm, dan bertanya kepada Nabi apakah kaum muliau. Jawaban Nabi serupa dengan bunyi hadîts di atas, tapi tanpa tambahan tentang berhubungan di atas unta. Masih dalam versi lainnya adalah tentang Qays Ibn Sad ibn 'Ubadah yang baru kembali dari hijrah. Jalan ceritanya mirip dengan cerita versi di atas. Dalam versi lainnya terdapat

40 Abû Abdillâh Aḥmad bin Muhammad bin Hanbâl asySyaibânî, Musnad Imam A $\underline{\bar{h}}$ mad, No. 19039, Juz, V, h. 515.

41 Abû 'Abdillah Mưhammad bin Yazîd ar-Rab'î al-Quzwainî Ibnu Mâjah, Sunan Ibnu Mâjah, Kitâb an-Nikâh, Bab Hak Suami atas Istri, No. 1907, Juz I, h. 595. 
tambahan bahwa, "seorang perempuan belum dipandang telah memenuhi kewajibannya kepada Tuhan kecuali jika ia telah memenuhi kewajibannya kepada suaminya. Jika ia diminta suaminya untuk melayaninya ketika ia sedang duduk di atas pelana kuda, maka ia harus mematuhinya. ${ }^{42}$

Dalam versi lain, Anas bin Mâlik meriwayatkan bahwa Nabi pernah bersabda "tidak ada seorang manusia pun yang boleh bersujud kepada sesamanya, dan jika seorang manusia diperbolehkan bersujud kepada sesamanya, saya akan menyuruh seorang istri bersujud kepada suaminya karena begitu besarnya hak seorang suami kepada istrinya. Demi Allah, jika seorang istri menjilat bisul yang tumbuh di sekujur tubuh suaminya, dari ujung kaki hingga ujung rambut, maka hal itu masih belum dianggap cukup sebagai pemenuhan kewajibannya kepada suaminya."43

Hadîts-hadîts tersebut menurut Khaled memberi pengaruh yang melebihi hadîts-hadîts lain yang menetapkan kewajiban hukum yang spesifik. Hadîts-hadîts teresebut menjelaskan sebuah prinsip mendasar yang mungkin dapat berdampak pada pola hubungan pernikahan dan relasi gender. Sementara praktik bersujud secara fisik kepada suami tidak diperkenankan, substansi moral dari sikap bersujud benarbenar diberlakukan atas dasar hadîts-hadîts semacam itu. Dampak nyata dari hadits-hadits tersebut adalah bahwa seorang istri mempunyai kewajiban yang sangat besar terhadap laki-laki yang menjadi suaminya, semata karena

42 Khaled Abou el-Fadl, Speaking in God's Name,h, 217.

43 Khaled Abou el-Fadl, Speaking in God's Name,h, 217. 
M. Rifian Panigoro, MA : Kritik Khaled Abou El-Fadl Atas Epistemologi Hadits Sujud pada Suami

posisi laki-laki tersebut sebagai suaminya. Seorang suami berhak mendapat penghormatan dan pelayanan dari istrinya. ${ }^{44}$

Khaled mengatakan bahwa hadîts-hadîts tersebut tidak bisa dipercaya karena kita tidak dapat menegaskan secara meyakinkan bahwa Nabi telah memainkan peranan penting dalam proses kepengarangan yang melahirkan hadîts-hadits tersebut. Bagi pihak tertentu, hadîts-hadîts tersebut bertentangan dengan gagasan teologis tentang kedaulatan Tuhan dan kehendak Tuhan yang bersifat mutlak. Khaled juga menilai bahwa hadîts-hadîts tersebut tidak selaras dengan diskursus al-Qur'an tentang kehidupan pernikahan. Dalam surah ar-Rûm ayat 21, al-Qur'an menyebutkan: "dan di antara tanda-tanda kekuasaanNya ialah Dia menciptakan untukmu istri-istri dari jenismu sendiri, supaya kamu cenderung dan merasa tenteram kepadanya, dan dijadikanNya di antaramu rasa kasih dan sayang." Al-Qur'an juga menggambarkan pasangan suami istri sebagai pakaian bagi satu sama lain. (QS. al-Baqarah [2]: 187). ${ }^{45}$

Selain itu, hadîts-hadîts tersebut tidak sejalan dengan keseluruhan riwayat yang menggambarkan perilaku Nabi terhadap istri-istrinya. Misalnya, al-Bukhârî menuturkan, ketika istri 'Umar sedang berdebat dengan suaminya, berkata "kamu memarahi saya karena beradu argumentasi dengan kamu! Demi Allah, istri-istri Nabi juga beradu argumentasi dengan beliau, bahkan salah seorang di antaranya meninggalkan beliau dari pagi hingga malam." Dalam riwayat al-Thayâlisî, salah satu istri Nabi bahkan beradu argumentasi dengan beliau hingga membuatnya marah. Lebih jauh lagi,

\footnotetext{
${ }^{44}$ Khaled Abou el-Fadl, Speaking in God's Name,h, 218.

45 Khaled Abou el-Fadl, Speaking in God's Name,h, 218.
} 
terdapat berbagai riwayat dari para istri Nabi yang meyatakan bahwa Nabi tidak pernah memukul atau mencela salah seorang istrinya, dan bahwa perlakuannya terhadap istriistrinya sangat lembut dan menyenangkan, dan bahwa ia sering meminta nasihat-nasihat istrinya.

Kemudian Khaled mengatakan bahwa hadîts ini mengalami proses kepengarangan yang menambahkan istri sujud kepada suaminya, seperti yang telah ditambahkan oleh komentator-komentator hadîts bahwa hadîts ini telah mengalami penambahan yang luar biasa fini ghayat almubalaghah) dengan munculnya tambahan tentang bukitbukit, pelana, punggung unta, dan bisul. 46

Pendapat selanjutnya dari Khaled ialah bahwasanya Hadîts-hadîts tentang kepatuhan terhadap suami ini bersumber dari Abû Hurairah. Kritik yang sangat menonjol terhadap Abû Hurairah adalah bahwa ia masuk Islam pada masa akhir kehidupan Nabi, yakni tiga tahun sebelum Nabi wafat dan meriwayatkan hadîts yang dinisbatkan kepada Nabi lebih banyak daripada hadits yang diriwayatkan oleh sabahatsahabat Nabi selama sekitar dua puluh tahun. Lebih jauh lagi, dibandingkan dengan para sahabat seperti Abû Bakr, 'Umar, 'Alî, atau Abî Dzâr al-Ghifâri, Abû Hurairah tampaknya tidak memiliki hubungan khusus dengan Nabi. Konsekuensinya, ada sejumlah besar riwayat yang menyebutkan bahwa beberapa sahabat seperti 'Â'isyah, 'Umar, dan 'Alî sangat mengkritisi Abû Hurairah karena meriwayatkan begitu banyak hadits. Para pengkritik itu menolak hadîts yang berasal dari Abû Hurairah ia dipandang baru masuk Islam dan meriwayatkan banyak hadîts yang bertentangan demgan hadîts-hadîts yang

46 Khaled Abou el-Fadl, Speaking in God's Name, h, 220. 
M. Rifian Panigoro, MA : Kritik Khaled Abou El-Fadl Atas Epistemologi Hadits Sujud pada Suami

diriwayatkan oleh sahabat yang lebih senior. Atas kritik tersebut Abû Hurairah menjawab bahwa bukan salahnya bila sahabat lainnya sibuk dengan urusan bisnis, ia tetap setia menemani Nabi, dan belajar darinya. Tentu saja, pengakuan tersebut secara implisit mereduksi peran para sahabat, yang pada gilirannya menjadikan kredibilitasnya semakin bertambah problematik. Dalam sebuah riwayat semacam itu, 'Â'isyah, memanggil Abû Hurairah agar menemuinya, dan kemudian ia berkata kepadanya, "Abû Hurairah! Apa maksud semua riwayat dari Nabi yang selalu kami dengar dari mulutmu! Katakan padaku, apakah kamu mendengar hal-hal dari Nabi yang tidak kami dengar, apakah kamu melihat sesuatu yang dilakukan Nabi yang tidak kami perhatikan?” Abû Hurairah menjawab, "wahai 'Umm al-mu'minîn, engkau sibuk dengan alis matamu dan mempercantik diri untuk Nabi, tapi saya, tidak ada yang memisahkan saya dari Nabi. ${ }^{47}$ Dalam sebuah riwayat serupa, Abû Hurairah selalu berkata, "sahabat dekat saya (khalîlî, maksudnya Nabi) berkata begini dan begitu, dan sahabat dekat saya melakukan ini dan itu." "Alî membantah Abû Hurairah dengan mengatakan, Abû Hurairah! Sejak kapan kamu menjadi sahabat dekat Nabi!"48

Riwayat lain menegaskan bahwa Abû Hurairah menentang riwayatnya sendiri, atau bahwa ia ditegur oleh sahabat lainnya, seperti Zubayr dan 'Umar. Pada kenyataanya, 'Umar diriwayatkan mengancam akan menghukumnya jika ia tidak membatasi diri dalam meriwayatkan hadîts. Dalam sebuah riwayat, 'Umar berkata kepada Abû Hurairah, Jika kamu tidak berhenti meriwayatkan hadits, saya akan

${ }^{47}$ Khaled Abou el-Fadl, Speaking in God's Name, h, 220.

48 Khaled Abou el-Fadl, Speaking in God's Name, h, 220 
mengasingkan kamu." Yang menarik adalah bahwa setelah 'Umar wafat, Abû Hurairah justru semakin menggiatkan periwayatannya, dan diriwayatkan pernah berkomentar bahwa jika 'Umar masih hidup, dia bisa mencambuknya karena semangatnya dalam meriwayatkan hadîts. ${ }^{49}$

Dari kritik yang dikemukakan oleh Khaled terhadap hadîts sujud pada suami, Khaled menawarkan sebuah konsep jeda ketelitian, ${ }^{50}$ yang dengan ini akan menggiring kita untuk tidak menggunakan hadits-hadîts tentang bersujud dan taat kepada suami sebagai sandaran dalam persoalan hukum atau teologi. dengan cara mengevaluasi secara menyeluruh semua hal yang bisa ditemukan dari hadîts-hadîts tersebut, kesadaran Khaled tetap terusik karena penilaiannya terhadap bukti-bukti yang ia temukan menggiringnya untuk berpikir bahwa sejauh yang ia ketahui hadîts tersebut kelihatannya autentik, atau menurutnya hadîts tersebut sangat bertentangan dengan pemahaman dan hubungan dia dengan Tuhan. kesadaran Khaled hanya terpuaskan jika ia benarbenar percaya bahwa hadits tersebut tidak autentik. Khaled sangat ingin meyakini bahwa Nabi tidak mengatakan hal semacam itu. Khaled menegaskan bahwa anggaplah bahwa

49 Khaled Abou el-Fadl, Speaking in God's Name, h, 220.

50 Jeda ketelitian adalah sebuah konsep yang ditawarkan Khaled jika terdapat hadîts yang menurutnya bermasalah. Jeda ketelitian dikutip dalam buku terjemahan dari buku asli milik Khaled yang berjudul Speaking in God's Name. yang dapat dipahami dari maksud jeda ketelitian tersebut adalah proses penangguhan dalam mengamalkan hadits sampai akhirnya dapat dibuktikan keotentikan hadits tersebut, dan pastinya keotentikan tersebut bukan seperti yang disyaratkan oleh para kritikus hadîts, keotentikan di sini sebagaimana yang diinginkan oleh Khaled, dengan metodologi yang ia inginkan. Khaled Abou el-Fadl, Atas Nama Tuhan; Dari Fikih Otoriter ke Fikih Otoritatif. Terj, Cecep Lukman Yasin, (Jakarta: Serambi, 2004), Cet, I, h. 317. 
M. Rifian Panigoro, MA : Kritik Khaled Abou El-Fadl Atas Epistemologi Hadits Sujud pada Suami

bukti-bukti yang ditemukannya menegaskan autentisitas hadîts tersebut, namun kesadarannya tetap terusik karena sebagai seorang muslim ia tidak percaya bahwa Nabi mengatakan hal semcam itu. Maka yang akan dilakukan Khaled kemudian ialah memposisikan diri sebagai pihak yang menyatakan keberatan berbasis iman, dan tidak menerima autentisitas hadîts tersebut. 51

\section{Kritik atas Pemahaman Khaled Abou El Fadl}

a. Penolakan Khaled Terhadap Periwayatan Abu Hurairah

Sebagaimana yang telah diuraikan sebelumnya, Khaled menolak Abû Hurairah dengan beberapa alasan. Yakni, karena Abû Hurairah masuk Islam di masa-masa akhir kehidupan Nabi, Abû Hurairah ditentang oleh sahabat-sahabat lain, Abû Hurairah dilarang Umar untuk meriwayakan hadîts."

Hadîts yang bersumber dari Abû Hurairah terdapat dalam Sunan tirmidzî, dan Tirmidzî menghukumi status hadîts ini sebagai hadîts hasan Shahîh $\underline{h} \cdot{ }^{52}$. Khaled bukanlah orang pertama yang mengkritik Abû Hurairah, sebelumnya telah ada di antaranya adalah Abû Rayyah ${ }^{53}$ dan Ahmad Amin ${ }^{54}$. Abû hurairah digoyahkan kredibilitasnya karena merupakan perawi hadits terbanyak, ${ }^{55}$ sehingga apabila

51 Khaled Abou el-Fadl, Speaking in God's Name, h, 221.

52 Muhammad 'Abd Raḩmân Ibnu 'Abd al-Rahîm alMubarakfuri, Tuhfat al-Ahwâadz bi Syarh Jâmi' al-Tirmidzî, (Beirut: Dâr al-Kutub al-Ilmiyyah, tth), 271.

53 Abû Rayyah, Syaikh al-Mudhirah Abû Hurairah, (Mesir: Dâr al-Ma'ârif, tth), h, 135.

${ }^{54}$ Ahmad Amin, Dhuhâ al-Islâm, (Mesir: Maktabah an-Nahdhat al-Mishriyyah, 1936), H, 72-73.

55 Abû Hurairah merupakan perawi hadîts terbanyak dengan jumlah hadits yang ia riwayatkan sejumlah 5374 buah hadits. 
kepercayaan umat Islam kepada Abû Hurairah telah luntur, maka sebagian besar hadîts-hadîts juga akan lenyap dari peredaran karena ia ditolak dan tidak dijadikan sebagai salah satu sumber Syariat Islam. ${ }^{56}$

Khaled mengkritik Abû Hurairah karena meriwayatkan hadîts dengan jumlah yang banyak melebihi para sahabat yang lebih senior dari dirinya. Abû Hurairah memang hanya tinggal selama kurang lebih empat tahun bersama Nabi, 57 tapi waktu yang singkat itu dimanfaatkan dengan sebaik-baiknya oleh Abû Hurairah. Disebutkan bahwa Abû Hurairah bermulâzamah hingga akhir kehidupan Nabi Saw. 58 Sebagaimana yang diriwayatkan oleh Bukhârî dalam Shahîhnnya:

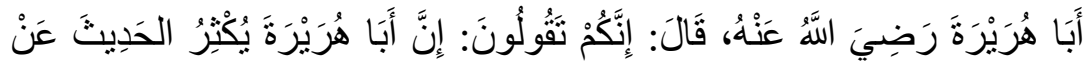

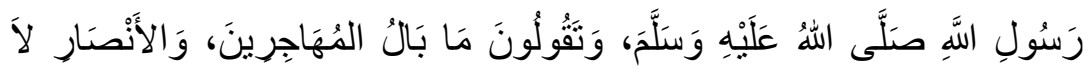

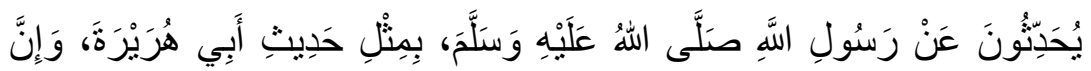

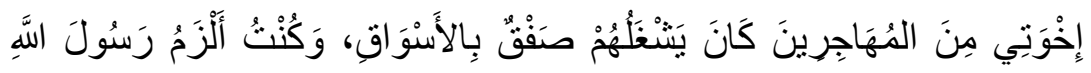

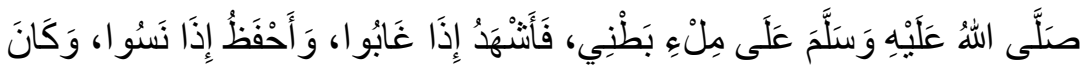

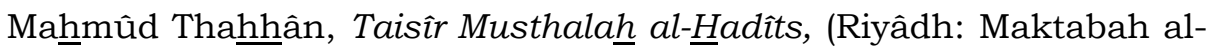
Ma'ârif li an-Nasyr wa at-Tauzî‘, 2004), h, 244.

56 Ali Mustafa Yaqub, Kritik Hadîts, (Jakarta: Pustaka Firdaus, 2008), h, 100.

${ }^{57}$ Abû Hurairah senantiasa bersama Rasul SAW selama empat tahun, yaitu semenjak kedatangannya di Khaibar hingga wafat Rasulullah SAW. Akan tetapi ada yang berpendapat bahwa dia bergaul bersama Rasul SAW hanya tiga tahun, karena selama setahun dia dikirim ke Bahrain bersama 'Ala' al-Hadhrami. Jadi dengan dikurangi setahun selama dia berada di Bahrain, maka masa dia bersama Rasul SAW adalah selama tiga tahun. Hal ini dihitung dari kedatangan Abû Hurairah di Khaibar pada tahun $7 \mathrm{H}$ dikurangi selisih tahun wafat Rasul $11 \mathrm{H}$. Muhammad 'ajjâj al-Khatîb, asSunnah Qabla at-tadwîn, (Kairo: Ummul Qurâ li at-Thabâ'ah wa anNasyr, 1988), h. 411-415. 412.

58 Muhammad 'ajjâj al-Khatîb, as-Sunnah Qabla at-tadwîn. h. 
M. Rifian Panigoro, MA : Kritik Khaled Abou El-Fadl Atas Epistemologi Hadits Sujud pada Suami

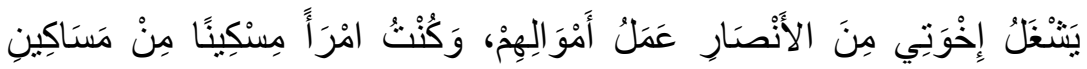

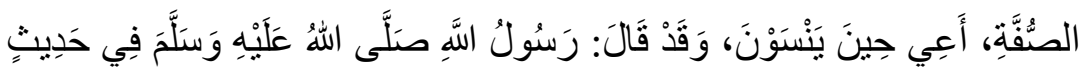

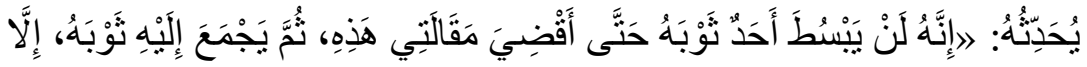

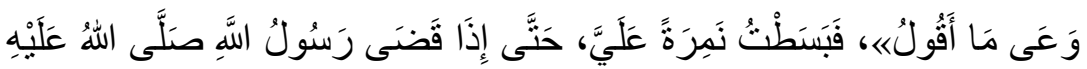

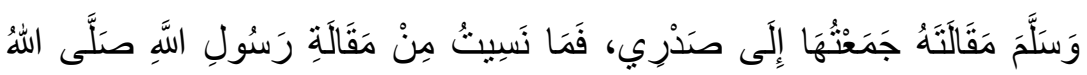

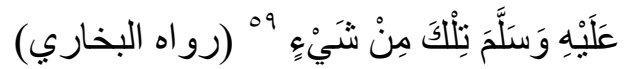

"Sesungguhnya Abû Hurairah berkata: Kalian akan menyatakan, bahwa Abû Hurairah banyak meriwayatkan hadîts. Dan Allahlah tempat (untuk membuktikan) janji. Juga mengatakan "Mengapa orang-orang Al Muhajirin dan Anshor tidak banyak meriwayatkan hadîts, seperti periwayatan Abû Hurairah?" Sungguh, saudara saudaraku dari Muhajirin disibukkan dengan jual beli di pasar. Sedangkan saudara-saudaraku dari Anshor disibukkan oleh pengelolaan harta mereka. Adapun aku seorang miskin yang selalu mengikuti Rasulullah selama perutku berisi. Aku hadir saat mereka tidak hadir, dan aku ingat dan paham saat mereka lupa.dan pada saat itu saudarasaudaraku dari anshor sibuk dengan harta mereka, sedangkan aku yang miskin dari Suffah, aku ingat disaat mereka lupa. Dan sungguh Rasulullah Saw bersabda pada suatu hadîts:sesungguhnya tidak ada yang menghampakan bajunya sampai aku menyelesaikan perkataanku ini, kemudian dia mengumpulkan bajunya itu kepadanya melainkan dia akan ingat apa yang aku katakan, maka aku hamparkan namirahku sampai rasul menyelesaikan perkataannya maka aku kumpulkan namirah ke dadaku. Maka aku tidak lupa sedikitpun dari perkataan rasul itu."

Riwayat inilah yang menjadi alasan kenapa Abû Hurairah meriwayatkan hadîts lebih banyak dari sahabatsahabat lainnya. Namun alasan ini tidak diterima oleh Khaled sebab baginya hal ini dapat mereduksi peran para

59 Abû 'Abdillah Muhammad bin Ismâ'il bin Ibrâhîm bin Mughîrah al-Bukhârî, Shahihh Bukharî, Kitâb al-Buyû', Bab Tentang Firman Allah Ta'alâ, (Tt: dâr Ibnu Katsîr, 1992), No. 2023, Juz II, h. 721. 
sahabat lainnya, yang menjadikan kredibilitas Abû Hurairah semakin bertambah problematik.

Alasan ini sebenarnya telah diketahui oleh Khaled, tetapi dia membangun sebuah opini baru bahwasanya apa yang dikatakan Abû Hurairah tersebut mereduksi peran sahabat yang lain. Seakan-akan sahabat lain tidak memiliki peran dalam periwayatan hadits. Hal ini tentu saja tidak seperti anggapan Khaled, ada beberapa faktor yang menyebabkan sahabat lain tidak banyak meriwayatkan hadîts. Sebagaimana yang terjadi pada Abû Bakar, ada 3 faktor yang menyebabkan Abû Bakar tidak banyak meriwayatkan hadîts, yakni: 60

1) Selalu sibuk saat menjabat sebagai khalifah.

2) Kebutuhan Hadîts tidak sebanyak pada zaman sesudahnya.

3) Jarak waktu antara wafatnya dengan kewafatan Nabi sangat singkat.

Inilah faktor yang menjadikan Abû Bakar tidak banyak meriwayatkan hadits, tapi sebagai sahabat dan khalifah pertama sejak Rasul wafat jelas menempatkan Abû Bakar sebagai orang yang sangat berperan dalam proses perkembangan Islam.

Faktor ketiga yang terjadi pada Abû Bakar, yakni singkatnya jarak waktu antara wafatnya Abû Bakar dan kewafatan Nabi tidak terjadi pada Abû Hurairah, Abû Hurairah wafat pada tahun $59 \mathrm{H},{ }^{61}$ sedangkan Rasulullah

60 Syuhudi Ismail, Kaedah Kesahihan Sanad Hadis, Telaah Kritis dan Tinjauan dengan Pendekatann Ilmu Sejarah, (Bandung :Bulan Bintang, 1995), h.43.

61 Nawer Yuslem, 'Ulumul hadits,(Jakarta: Mutiara Sumber Widya, 1988), h. 445. 
M. Rifian Panigoro, MA : Kritik Khaled Abou El-Fadl Atas Epistemologi Hadits Sujud pada Suami

Saw wafat pada tahun 11 H. 62 Selisih 48 tahun dari wafatnya Nabi sampai wafatnya Abû Hurairah inilah yang menjadi salah satu faktor banyaknya hadîts yang diriwayatkan Abû Hurairah. Karena Selain Abû Hurairah meriwayatkan hadîts dari Nabi. Abû Hurairah juga memiliki banyak kesempatan meriwayatkan banyak hadîts dari sesama sahabat. Di antaranya diriwayatkan dari Abû Bakar, 'Umar, 'Utsmân, Ubai bin Ka'ab, 'Utsman bin Zaid, 'A'isyah dan sahabat lainnya. 63

Hal ini juga dapat dilihat pada sahabat-sahabat lain yang terkenal banyak meriwayatkan hadîts. 'Abdullah bin 'Umar meriwayatkan 2630 hadîts, lahir pada tahun $10 \mathrm{SH}$ dan wafat pada $73 \mathrm{H}$. Anas bin Mâlik meriwayatkan 2286 hadîts lahir pada tahun $10 \mathrm{SH}$ dan wafat pada tahun $93 \mathrm{H}$. Aisyah binti Abû Bakar meriwayatkan 2210 hadîts, lahir tahun $9 \mathrm{SH}$ dan wafat pada tahun $58 \mathrm{H}$. 'Abdullah bin Abbâs meriwayatkan 1660 hadîts, lahir pada tahun $3 \mathrm{SH}$ dan wafat pada tahun 68 H. Jabir bin 'Abdillah meriwayatkan 1540 hadîts, lahir pada tahun $6 \mathrm{SH}$ dan wafat pada tahun $78 \mathrm{H}$. Abû Said al-Khudrî meriwayatkan 1170 hadîts, lahir pada tahun $12 \mathrm{SH}$ dan wafat pada tahun 74 H. ${ }^{64}$ Ketujuh periwayat hadîts ini memiliki selisih waktu yang panjang dari wafatnya Rasul hingga wafatnya mereka, hal ini menjadi bukti yang kuat bahwasanya selisih ini mempengaruhi jumlah hadîts yang diriwayatkan oleh Sahabat.

62 Shafiyyurahmân al-Mubârakfuri, ar-Rahîq al-Makhtûm, terj. Agus Suwandi, (Jakarta: Ummul Qura, 2012), h. 824.

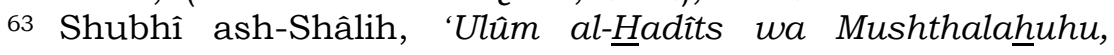
(Beirût: Dâr al-'Ilm li al-Malâyîn, 1984), h. 361.

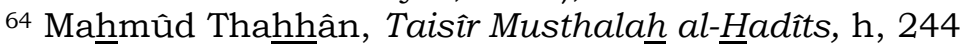


Faktor lainnya yang menjadikan Abû Hurairah banyak meriwayatkan hadits ialah karena kekuatan hafalannya, sebab Abû Hurairah dido'akan lanngsung oleh Nabi sebagaimana yang diriwayatkan dalam shahîh Bukhârî:

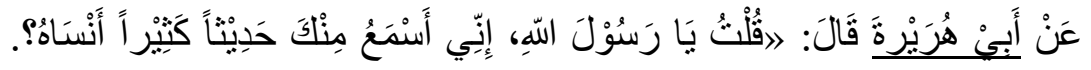

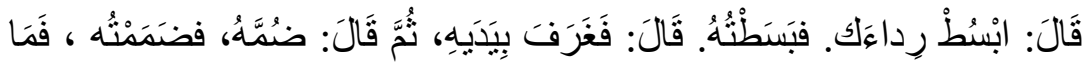

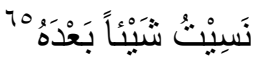

"Abî Hurairah, ia berkata, "Wahai Rasulullah, aku banyak menerima hadits darimu, tapi aku banyak lupa". Rasulullah bersabda: "bentangkanlah jubahmu!" maka aku membentangkan jubahku. Kemudian Rasulullah menciduk dengan kedua tangannya dan berkata: "satukanlah!" Lalu aku satukan dan setelah itu aku tidak lupa lagi."

Kemudian perihal 'Â'isyah, menolak hadîts Abû Hurairah, pertentangan antara 'A'isyah dan Abû Hurairah memang pernah terjadi, salah satu kejadiannya adalah dalam hadîts yang diriwayatkan oleh Abû Hurairah, yakni:

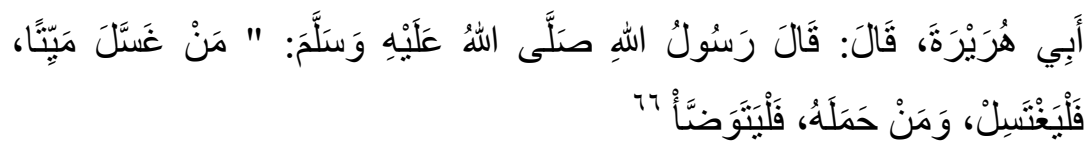

"Abû Hurairah, Rasulullah Saw bersabda: barangsiapa memandikan mayat maka hendaklah mandi, dan barangsiapa yang memikulnya maka hendaklah berwudhu."

Pada kasus ini 'Â'isyah menolaknya dengan alasan dia dan sahabat lain meriwayatkan hadîts tanpa tambahan

65 Al-Bukhârî, Shahîh al-Bukhârî, Kitâb al-'ilm, Bâb Hifzh al'Îlm, No. 119. Juz, I, h. 56

66 Abû Abdillâh Aḥmad bin Muhammad bin Hanbâl asySyaibâni, Musnad Imâm Ămad, No. 9706, Juz, III, h. 210. 
M. Rifian Panigoro, MA : Kritik Khaled Abou El-Fadl Atas Epistemologi Hadits Sujud pada Suami

berwudhu ketika memikul mayat 67 'Â'isyah berkata "najiskah mayat-mayat muslim itu? Kalau begitu, apa yang harus dilakukan oleh orang yang memikul kayu bakar? (apakah ia wajib berwudhu atau tidak?). 'Â'isyah memahami perintah bagi yang memandikan mayat, misalnya dikarenakan najis yang keluar dari si mayat, tetapi mengenai perintah wudhu bagi yang memikul mayat, baginya merupakan suatu kejanggalan. 68

Namun hal ini telah dibahas oleh Musthafâ asSibâ'î, kejadian ini sebagai dalil bahwa sahabat berbeda pendapat antara satu dengan lainnya, dan saling merendahkan kedudukan antara satu dan lainnya, dan semua yang terjadi antara para sahabat tentang perbedaan pendapat antara mereka, sesungguhnya itu murni diskusi ilmiah. Lahir dari perbedaan pandangan dan kemampuan mereka dalam beristinbat dan berijtihad, atau karena lupanya seseorang diantara mereka terhadap suatu hadîts. dan yang lainnya mengingat hadîts itu. dan ini bukan merupakan dasar timbulnya keraguan dan pengingkaran antara satu dan lainnya. Untuk itu wajib memahami semua diskusi yang terjadi antara Abû Hurairah dan sahabat

67 Nabi mandi pada empat tempat, yakni setelah junub, padahari jum'at, setelah berbekam, dan setelah memandikan mayat. ini adalah hadîts yang diriwayatkan Aisyah yang menyatakan bahwa tidak ada perintah berwudhu setelah memikul mayit. Abû Dâwûd Sulaimân bin al-'asy'ats bin Ishâq bin Basyîr al-Azdî as-Sijistânî, Sunan Abî Dâwîd, (Beirût: Dâr Ihyâ' at-Turâts al-'Arabî), No. 348. juz II, h. 13.

68 Shalâh ad-Din bin Ahmad al-Adlâbi, Minhâj Naqd al-Matan, (Beirût: Dâr al-Afâq al-Jadîdah,tt ), , h. 116. 
lainnya, dan tidak dibenarkan membawa prasangka ini kepada prasangka lainnya. ${ }^{69}$

Dan yang memperkuat pendapat Mustafa as-Siba'i adalah hadîts yang diriwayatkan dalam Musnad Ahmâd bin Hanbal, dalam hadîts ini disebutkan bahwa 'Â'isyah menerima apa yang diriwayatkan Abû Hurairah, berikut redaksi haditsnya:

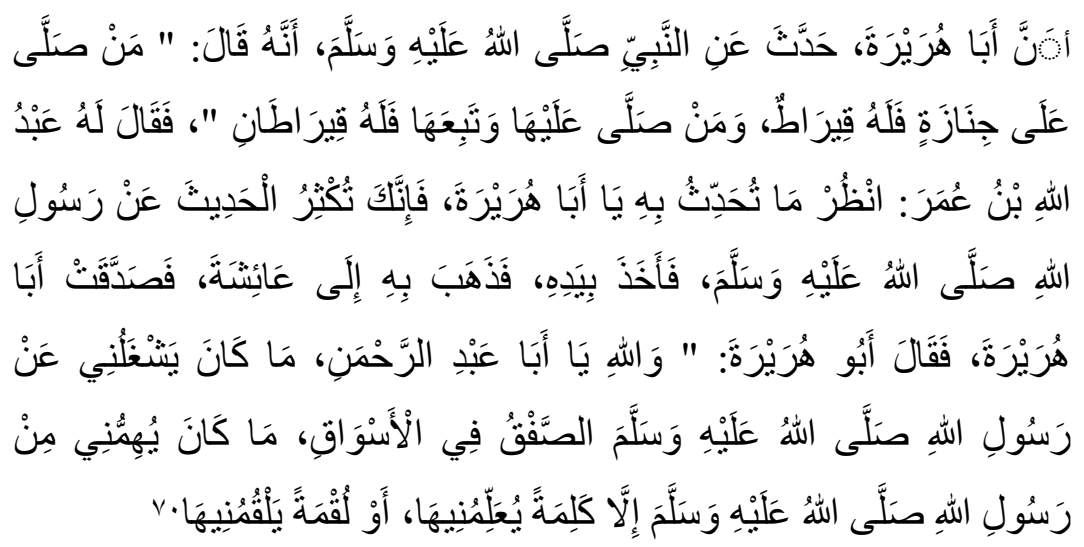

"Abû Hurairah menceritakan dari Nabi Saw, beliau bersabda: Barangsiapa menshalati jenazah maka ia mendapatkan pahala satu qirâth, dan barangsiapa menshalatinya kemudian mengiringinya hingga kuburan maka ia mendapatkan pahala dua qirâth. Kemudian 'Abdullah bin 'Umar berkata kepada Abû Hurairah, Lihatlah yang telah kamu ceritakan wahai Abû Hurairah, sesungguhnya kamu telah menambahi hadîts dari Rasulullah shallallahu 'alaihi wasallam, lalu 'Abdullah bin 'Umar memegang tangan Abû Hurairah dan membawanya kepada 'Â'isyah, namun 'Â'isyah membenarkan Abû Hurairah. Kemudian Abû Hurairah berkata; "Demi Allah wahai Abû 'Abdurrahmân, sesungguhnya aku tidak disibukkan perdagangan di pasar dari menghadiri Majelis Rasulullah shallallahu 'alaihi wasallam. Dan tidak ada yang menjadikan aku mementingkannnya dari menghadiri

69 Musthafâ as-Sibâ'î, as-Sunnah wa Makânatuhâ fî at-Tasyrî‘ al-islâmi, h. 331-332.

70 Abû Abdillâh Ahmmad bin Muhammad bin Hanbâl asySyaibâni, Musnad Imâm Ăㅡmad, Juz III, h. 90. 
M. Rifian Panigoro, MA : Kritik Khaled Abou El-Fadl Atas Epistemologi Hadits Sujud pada Suami

majelis Rasulullah Saw kecuali kalimat yang ia ajarkan kepadaku, atau satu suap yang ia berikan kepadaku."

Kritik Khaled selanjutnya terhadap Abû Hurairah dikutip dari Bidâyah wa an-Nihâyah Dalam sebuah riwayat, 'Umar berkata kepada Abû Hurairah, "Jika kamu tidak berhenti meriwayatkan hadits, saya akan mengasingkan kamu." 71 Pernyataan "Umar ini disebabkan kekhawatirannya jika terjadi pendustaan atas nama Rasulullah Saw. Ia takut bahwa mereka meriwayatkan hadîts, padahal mereka tidak hafal dan tidak dapat memahaminya dengan benar. Orang yang sedikit meriwayatkan hadîts lebih dapat mengingat hadîts yang diriwayatkan daripada orang yang banyak meriwayatkan dan ia lebih jauh dari kemungkinan lupa dan keliru. ${ }^{72}$

Namun 'Umar akhirnya mengizinkan Abû Hurairah meriwayatkan hadîts, ketika 'Umar telah mengetahui sifat wara' dan khasyyah Abû Hurairah terhadap Allah. Yakni ketika Abû Hurairah menyampaikan sebuah hadîts kepada 'Umar yang menyatakan: Siapa yang berdusta atas namaku dengan sengaja maka dia telah menyediakan tempatnya di neraka. ${ }^{73}$

Semenjak ini 'Umar tidak lagi membatasi Abû Hurairah dalam meriwayatkan hadîts. ${ }^{74}$ Dengan penjelasan ini dapat diketahui bahwasanya pernayataan 'Umar yang

${ }^{71}$ Khaled Abou el-Fadl, Speaking in God's Name,h, 218.

72 Muhammad 'ajjaj al-Khatib, al-Sunnah Qobla al-Tadwîn, (Kairo: Maktabah Wahbah, 1988), hlm 100.

73 Abû al-Husain Muslim bin al-Hajjâj bin Muslim al-Qusyairi an-Naisâbûrî, Shahîh Muslim, Bâb Taglîzh al-Kadzb 'alâ Rasûlillâh, (Beirût: Dâr al-Kutüb al-Ilmiyah, 1992), juz 1, h. 65.

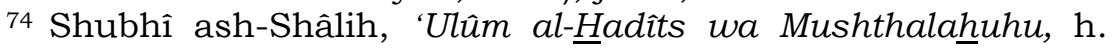
361. 
dikutip oleh Khaled bukanlah sesuatu yang bersifat final, karena setelahnya 'Umar mengizinkan Abû Hurairah untuk meriwayatkan hadits.

Kritik selanjutnya dari Khaled terhadap Abû Hurairah adalah protes yang timbul dari 'Alî bin Abî Thâlib. 'Alî mempertanyakan kedekatan Abû Hurairah dengan Nabi (sejak kapan engkau bersahabat dekat dengan Nabi), sebab Abû Hurairah sering mengatakan "sahabat dekat saya (Khalîlî) berkata begini dan begitu." Khaled menganggap pertanyaan yang dilontarkan oleh 'Alî adalah sebuah bentuk ketidaksetujuan 'Alî terhadap Abû Hurairah. Namun Khaled mengutip riwayat ini dari 'Abdul Husein Syaraf ad-Dîn al-Musâwî dalam bukunya yang berjudul Abû Hurairah. Seperti yang diketahui bahwasanya alMusâwî adalah orang yang berideologi Syî‘ah yang mencela Abû Hurairah. 75 Kemudian Khaled juga mengambil pernyataan ini dari Ibnu Qutaibah dalam kitab ta'wîl nya. ${ }^{76}$

Al-Musâwî mengatakan pada bab dukungan Bani 'Umayyah kepada Abû Hurairah: "Sebelum berdaulatnya bani Umayyah, Abû Hurairah merupakan seorang yang hina dan lemah, seorang yang hanya mencari kutu yang merayap di bajunya. Sedangkan keadaan Abû Hurairah semasa berkuasanya bani 'Umayyah, berubah setelah mereka (bani Umayyah) mengambilnya dan mengeluarkannya dari kesusahan dan kesulitan lalu mereka memakaikan kepadanya sutera."77

75 Syaraf ad-dîn al-Musâwî. Menggugat Abû Hurairah: Menelusuri Jejak Langkah dan hadist-hadistnya,Terj. Mustofa Budi Santoso. (Jakarta: Pustaka Zahra, 2002). H. 45.

76 Muhammad 'Abdullah bin Muslim al-Qutaibah, Ta'wîl

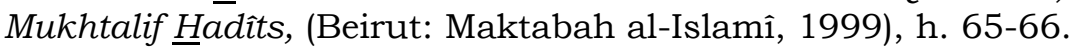

77 Syaraf ad-dîn al-Musâwî. Menggugat Abû Hurairah: Menelusuri Jejak Langkah dan hadist-hadistnya, h. 45. 
M. Rifian Panigoro, MA : Kritik Khaled Abou El-Fadl Atas Epistemologi Hadits Sujud pada Suami

Al-Musâwî juga mengatakan bahwa Abû Hurairah sebenarnya adalah hamba bani 'Umayyah dan haditshadîts yang diucapkan oleh Abû Hurairah adalah hadîtshadîts rekaan, dan semata-mata diucapkan oleh Abû Hurairah sesuai pesanan orang-orang durhaka dan juga untuk membela orang-orang munafik dari kalangan bani 'Umayyah. 78

Berdasarkan hal ini dapat dipahami bahwa apa yang dikatakan oleh al-Musâwî hanyalah celaan terhadap Abû Hurairah. Dan Khaled mengutip pernyataan ini sebagai bahan dukungan kritiknya terhadap Abû Hurairah. Yang menarik adalah kenapa Khaled tidak mempertimbangkan penilaian-penilaian positif terhadap Abû Hurairah. 79 Melainkan mencari pembenaran dari orang-orang yang dari awalnya mengkafirkan Sahabat.

Sedangkan dalam kitab ta'wîl Ibnu Qutaibah, Ibnu Qutaibah memaparkan penjelasan dari Abû Hurairah terkait khalîlî yang dikatakannya. Abû Hurairah mengatakan bahwa khalîtî dalam hal ini adalah pertemanan dekat berbeda dengan khalîlî yang ada dalam Al-Qur'an,

78 Syaraf ad-dîn al-Musâwî. Menggugat Abû Hurairah: Menelusuri Jejak Langkah dan hadist-hadistnya, h. 48.

79 'Umar mengatakan "sesungguhnya engkau (Abû Hurairah) paling sering menemani Rasulullah sallahu 'alaihi wa sallam dan yang paling hafal haditsnya dari pada kami." Asy-Syâfi'i mengatakan "Abu Hurairah adalah yang paling hafal dari semua yang meriwayatkan hadist di jamannya." Bukhârî juga memberikan penilaian terhadap Abu Hurairah, yakni "telah meriwayatkan darinya (abû horairah) sekitar 800 dari ahlu ilmu (ulama perawi hadist), dan merupakan yang paling hafal hadist di jamannya." Dan para "Alîm lainnya seperti Ibnu Hajar dan Abû Nu'aym juga memberikan pengakuannya terhadap kualitas hafalan Abû Hurairah. Lihat, Musthafâ as-Sibbâ'î, asSunnah wa Makânatuhâ fî at-Tasyrî‘ al-islâmi, h. 328. 
an-Nisâ' ayat 125. Semua orang mukmin bersaudara, dan dalam hal ini Rasulullah Saw adalah khalîlî ummatnya. 80

Apa yang dilakukan oleh 'Alî hanyalah sebuah bentuk klarifikasi terhadap Abû Hurairah, bukan sebagai bentuk penolakan atas periwayatannya. Khaled hanya mengambil perkataan awal Ibnu Qutaibah dalam kitab ta'wîl ini, padahal di halaman-halaman berikutnya Ibnu Qutaibah memaparkan apa yang menjadi masalah dalam hal itu. Ini menandakan bahwa Khaled mencari legitimasi dari kitab-kitab ulama ahl al-Sunnah sehingga seakan-akan ulama itu ikut menolak Abû Hurairah.

b. Tidak Sejalan dengan Diskursus al-Qur'an

Dari segi matan, Khaled menolak hadîts ini dengan sebab bertentangan dengan diskursus al-Qur'an surah arRûm ayat 21 dan surah al-Baqarah ayat 187.

Menurutnya Al-Qur'an mengajarkan cinta kasih bukan ketundukan salah satu pasangan atas pasangan lainnya. (ketundukan Istri terhadap suami). Dalam hal ini Khaled termasuk orang yang terburu-buru menghukumi suatu hadits, hanya karena makna suatu hadîts bertentangan dengan Al-Qur'an. Dan yang demikian ini tidak akan dilakukan oleh orang-orang yang mendalam ilmunya. Karena kepercayaan mereka terhadap para tokoh terdahulu. Apabila telah diterima dengan baik oleh mereka, maka diyakini bahwa mereka tidak menemukan adanya keganjilan dalam hadîts tersebut. 81

80 Muhammad Abdullah bin Muslim al-Qutaibah, Ta'wîl Mukhtalif Hadits, (Beirut: Maktabah al-Islamî, 1999), h. 65-66.

81 Yûsuf al-Qardhâwî, Kaifa Nata'âmal as-sunnah amNabawiyyah, (Dâr al-Wafâ' li at-Thabâ'ah wa an-Nasyr wa at-Tauzî', 1993), h. 45-46. 
M. Rifian Panigoro, MA : Kritik Khaled Abou El-Fadl Atas Epistemologi Hadits Sujud pada Suami

Pernyataan bahwa tidak ada hadîts-hadîts yang bertentangan dengan Al-Qur'an dapat kita lihat dari pernyataan-pernyataan para ulama, asy-Syâfi'î mengatakan bahwa adalah sesuatu yang mustahil apabila Sunnah Nabi Saw bertentangan dengan Al-Qur'an. ${ }^{82}$ Hadîts apabila menyelisihi tekstual Al-Qur'an, tertolak," merupakan suatu kejahilan. 83 Ibnu 'Abdil Barr juga memberikan pandangan bahwasanya Allah telah memerintahkan kita untuk menataati Rasul-Nya dan diperintahakan untuk mengikuti petunjuk Rasul-Nya secara mutlak dan dalam perintah tersebut tidak dikaitkan dengan syarat apa pun. Oleh karena itu mengikuti beliau sama halnya dengan mengikuti Al-Qur'an. Sehingga tidak boleh dikatakan, kita mau mengikuti Nabi Saw asalkan bersesuaian dengan Al-Qur'an. Sungguh perkataan semacam ini adalah perkataan orang yang menyimpang." 84

Hadîts sujud kepada suami yang diriwayatkan lewat jalur at-Tirmidzî telah dikomentari oleh al-Mubârakfuri dalam kitab Tuḩfah al-Ahwâdzi Syarh Sunan at-Tirmidzî, dikatakan oleh Mubârakfuri bahwa kalimat (لأمرت المرأة أن تسجد disebabkan oleh banyaknya hak-hak suami atas istrinya, dan begitu lemahnya syukur seorang istri terhadap hak-hak ini. ${ }^{85}$ Dan kalimat (لأمرت المرأة أن تسجد لزوجها) dalam hadîts ini merupakan majas yang sangat hiperbola

${ }^{82}$ Muhammad bin Idrîs asy-Syâfi'î, ar-Risâlah, (Beirût: Dâr alKutub al-Ilmiyyah, tth), h. 546

83 Muhammad bin Idrîs asy-Syâfi'în, Ikhtilâf Hadîts, (Beirût: Dâr al-Kutub al-Ilmiyyah, 1986), h. 59.

84 Abî 'Amr Yûsuf bin 'Abd al-Barr, Jâmi' bayân 'ilm wa fadhl, (Riyâdh: Dâr Ibnu al-Jauzî', 1994), h. 190.

85 Muhammad 'Abd Raḩmân Ibnu 'Abd al-Rahîm alMubarakfuri, Tuhfat al-Ahwâdz bi Syarh Jâmi' al-Tirmidzî, (Beirut: Dâr al-Kutub al-Ilmiyyah, tth), h. 323. 
sebagai gambaran wajibnya seorang istri untuk taat kepada suaminya. Dikatakan suatu majas karena sesungguhnya sujud ini tidak dibolehkan kepada siapapun kecuali Tuhan. 86

Dari syarh h hadîts ini dapat dilihat bahwa tidak ditemukan komentar ulama yang mengaitkan hadîts ini kepada sesuatu hal yang bertentangan dengan Al-Qur'an. Tidak disebutkan adanya pertentangan hadits ini dengan Al-Qur'an surah ar-Rûm ayat 21 dan juga surah alBaqarah ayat 187.

Ibnu Katsîr menafsirkan Surah ar-Rûm ayat 21 dengan mengatakan bahwa rahmat Tuhan kepada manusia ialah menjadikan pasangan-pasangan mereka dari jenisjenis mereka sendiri serta menjadikan perasaan cinta kasih sayang di antara mereka. Di mana seorang laki-laki mengikat seorang wanita kadangkala dikarenakan rasa cinta atau rasa kasih sayang dengan lahirnya seorang anak, saling membutuhkan nafkah dan kasih sayang di antara keduanya. 87

Hal ini berkaitan erat dengan sebuah ikatan yang dilakukan oleh laki-laki dan perempuan yakni pernikahan, ketika dua insan dipersatukan dalam pernikahan maka keduanya memiliki hak dan kewajiban masing-masing. Olehnya di dalam kitab-kitab hadîts yang disusun berdasarkan bab-bab fiqih (Sunan) kita dapat melihat adanya pembagian bab hadîts hak-hak suami yang wajib atas istri dan hak-hak istri yang wajib atas suami. Dan h. 323.

86 al-Mubarakfuri, Tuhfat al-A $\underline{h} w a ̂ d z$ bi Syarh Jâmi‘ al-Tirmidzî,

87Abû al-Fidâ Ismâ'il Ibnu Katsîr al-Qurâsî al-Damasyqî, Tafsîr Ibnu Katsîr, (Beirut: Dâr ihyâ al-Turâts al-Arabî, 1985), Juz VI, h. 277. 
M. Rifian Panigoro, MA : Kritik Khaled Abou El-Fadl Atas Epistemologi Hadits Sujud pada Suami

hadîts tentang sujud kepada suami termasuk dalam babbab tersebut. Sesuai fungsi hadîts yang menjadi penjelas dari Al-Qur'an, 88 maka hadîts sujud kepada suami lebih mengarah kepada pentakhshîshan Al-Qur'an surah ar-Rûm ayat 21 .

Mubârakfuri dalam tuhfatul ahwâdzi menyebutkan bahwa hadîts ini disebabkan oleh betapa lemahnya rasa syukur seorang istri terhadap hak-hak ini, dan keterangan seperti itu dapat dilihat dalam hadîts Nabi Saw:

"Rasulullah Saw bersabda: Aku diperlihatkan neraka, penghuninya mayoritas adalah perempuan, sebab mereka ingkar. Apakah mereka ingkar kepada Allah?, Rasulullah menjawab: mereka ingkar kepada suami dan kebaikan orang. Jikalau kamu berbuat baik kepada mereka sepanjang masa, kemudian mereka (kaum perempuan) melihat sesuatu yang tidak baik dari diri kamu, maka mereka akan mengatakan "aku tidak pernah memperoleh kebaikan sedikitpun dari kamu."89

Hadîts tentang sujud pada suami (hak-hak suami atas istri) menjadi penyeimbang apabila pengaruh buruk yang ditimbulkan dari lemahnya rasa syukur seorang istri benar-benar terjadi. Terlebih al-Mundzirî mengkategorikan hadîts ini sebagai hadîts Targhîb wa Tarhîb. 90 Sehingga menjadi dorongan bagi seorang istri untuk taat kepada suami. Suami pun tak lepas dari tuntutan-tuntutan yang menjadi hak seorang istri. Dalam bab hak-hak istri atas suami salah satu hadîts disebutkan:

\footnotetext{
88 Muhammad bin Idrîs asy-Syâfi'î, Ikhtilâf Hadits, h.

89 Al-Bukhârî, Shahîh al-Bukhârî, Kitab al-îmân, Bab Mengingkari Suami dan Küur akbar, Juz, I, h. 19.

90 Abd al-'Âzhim bin Abd al-Qâwî al-Mundzirî, al-Targhî̉ wa alTarhîb, (Riyâdh: Maktabah al-Ma'rif li an-Nasyr wa at-Tauzî‘ 1424 H). Juz, III, h. 36.
} 
"Rasulullah Saw bersabda: Engkau memberinya makan jika engkau makan, engkau memberinya pakaian jika engkau berpakaian, janganlah memukul wajah dan janganlah menjelek-jelekkannya serta janganlah memisahkannya kecuali tetap dalam rumah.

Selanjutnya perihal bertentangannya hadîts tentang sujud kepada suami ini dengan surah al-Baqarah ayat 187 , Ibnu katsîr menyebutkan bahwa ini merupakan keringanan dari Allah bagi kaum muslimin serta penghapusan hukum yang sebelumnya berlaku pada permulaan Islam pada saat itu. Jika seorang dari kaum muslimin berbuka puasa, maka dihalalkan baginya makan, minum, dan berhubungan badan sampai shalat isya'atau ia tidur sebelum itu. Jika ia sudah tidur atau shalat isyâ', maka diharamkan baginya makan, minum dan berhubungan badan sampai malam berikutnya. Dan karena ini para sahabat merasa sangat keberatan. 92

Sabâb an-Nuzûl ayat ini adalah ketika Qais bin Sharîmah al-Anshâr pernah dalam keadaan puasa bekerja seharian di ladang miliknya, dan ketika waktu buka tiba, ia menemui istrinya dan bertanya: "apakah engkau punya makanan?" istrinya menjawab: "tidak, tetapi aku akan pergi mencarikan makanan untukmu." Maka Qais terkantuk dan ia pun tertidur. Ketika istrinya datang, dan melihat suaminya tertidur, ia pun berkata "merugilah engkau mengapa engkau tidur?” pada waktu siang hari

91 Abû Dâwûd, Sunan Abî dâwûd, Kitâb an-Nikâh, Bab Hak-hak Istri atas Suami, No. 2146, Juz, VI, h. 180.

92 Ibnu Katsîr, Tafsîr Ibnu Katsîr, Juz, I, h. 384. 
M. Rifian Panigoro, MA : Kritik Khaled Abou El-Fadl Atas Epistemologi Hadits Sujud pada Suami

Qais pun jatuh pingsan. Lalu hal itu diceritakan kepada Nabi Saw, maka turunlah ayat ini. 93

Jika dilihat dari apa yang disebutkan oleh Ibnu Katsîr serta kaitannya dengan Sabâb an-Nuzûl ayat tersebut, tidak ada pertentangan yang terjadi antara hadîts sujud kepada suami dan surah al-Baqarah ayat 187. Ayat ini berbicara tentang penghapusan hukum sebelumnya yang di dalamnya disebutkan bahwa halal berhubungan badan di malam hari hingga nampak olehmu benang putih dan benang hitam. Dan dalam hal berhubungan suami istri, baik istri dan suami sama-sama memiliki hak dalam hal ini, sebagaimana yang diriwayatkan dalam Shahîh Bukhârî tentang hak seorang suami dalam hubungan suami istri:

"Abî Hurairah r.a berkata: Rasulullah Saw bersabda: Apabila seorang suami mengajak istrinya ke tempat tidur lalu dia menolaknya, dan membuat suaminya marah. Maka malaikat akan melaknatnya hingga shubuh". ${ }^{94}$

Adapun hak seorang istri dalam hubungan suami istri sebagaimana yang tertuang dalam hadîts berikut ini:

"Rasulullah Saw bersabda: "Hai 'Abdullah, apakah tidak aku kabarkan sesungguhnya kamu berpuasa pada siang hari dan beribadah pada waktu malam?" Aku menjawab: "Benar Ya Rasulullah." Rasulullah bersabda:"Jangan kamu lakukan itu, berpuasa dan berbukalah, beribadah dan tidurlah, sesungguhnya bagi tubuhmu ada hak atasmu, bagi dua matamu ada hak atasmu dan bagi isterimu ada hak atasmu." ${ }^{95}$

93 Ibnu Katsîr, Tafsîr Ibnu Katsîr, Juz, I, h. 384.

94 Al-Bukhârî, Shahîh Bukhârî, Kitâb Bad'i al-Khalqi, Bâb Idz Qâla ahadukum “âmîn” wa al-Malâ'ikatu fî as-Samâ', No. 3167, Juz, III, h. 182 .

95 Al-Bukhârî, Shahîh Bukhârî, Kitâb an-Nikâh, Bab Bagi Istrimu Ada Hak atas Kamu, No. 5199, Juz, V, h. 1995. 
M. Rifian Panigoro, MA : Kritik Khaled Abou El-Fadl Atas Epistemologi Hadits Sujud pada Suami

c. Penambahan Pada Redaksi Hadits

Kritik selanjutnya yang diberikan oleh Khaled adalah dengan mengatakan bahwa hadîts ini telah mengalami penambahan sujud pada suami, setelah sebelumnya ada pelarangan dari Nabi umtuk sujud kepada beliau. Khaled beranggapan bahwa Nabi hanya mengatakan untuk tidak sujud kepada beliau kemudian ada proses penambahan sujud pada suami pada kalimat berikutnya. Dan hadîts ini juga mengalami penambahan yang luar biasa (fîhi ghâyat al-mubâlaghah) dengan munculnya tambahan tentang bukit-bukit, pelana, punggung unta, dan bisul.

Adapun hadîts yang dimaksud Khaled, yang didahului oleh pelarangan Nabi untuk sujud kepadanya dan kemudian diakhiri dengan penyebutan pelana kuda ialah:

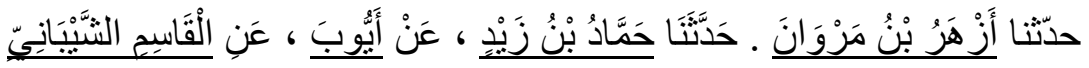

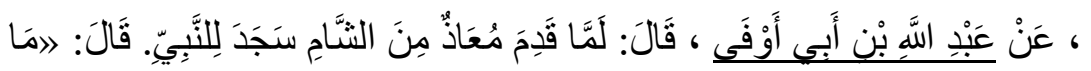

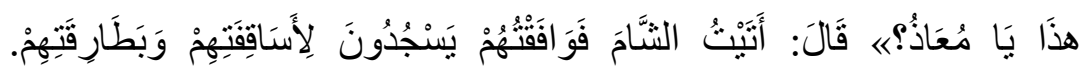

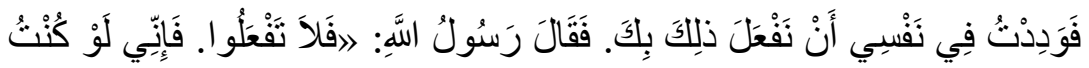

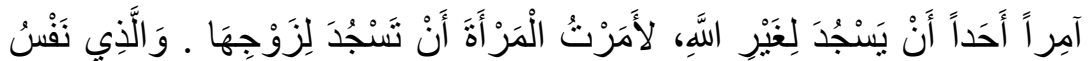

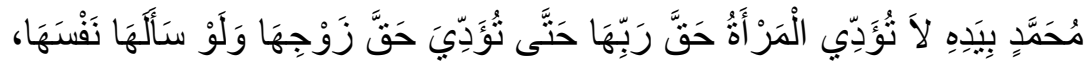

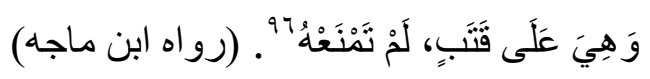

Dalam sanad hadîts ini terdapat seorang rawi yakni al-Qâsim al-Syaibânî yang diperbincangkan periwayatannya. Beragam penilaian terhadap al-Qâsim al-Syaibânî

96 Ibnu Mâjah, Sunan Ibnu Mâjah, Kitâb an-Nikâh, Bab Hak Suami atas Istri, No. 1907, Juz, I, h. 595. 
M. Rifian Panigoro, MA : Kritik Khaled Abou El-Fadl Atas Epistemologi Hadits Sujud pada Suami

yakni, Mudhtarib al- $\underline{\text { Haditts }}{ }^{97}$ dan dha' $\hat{\imath} f,{ }^{98}$ Sehingga kualitas hadîts ini adalah dhaif. 99

Hadîts selanjutnya ialah yang menunjukkan tambahan bukit-bukit setelah menyebutkan sujud kepada suami.

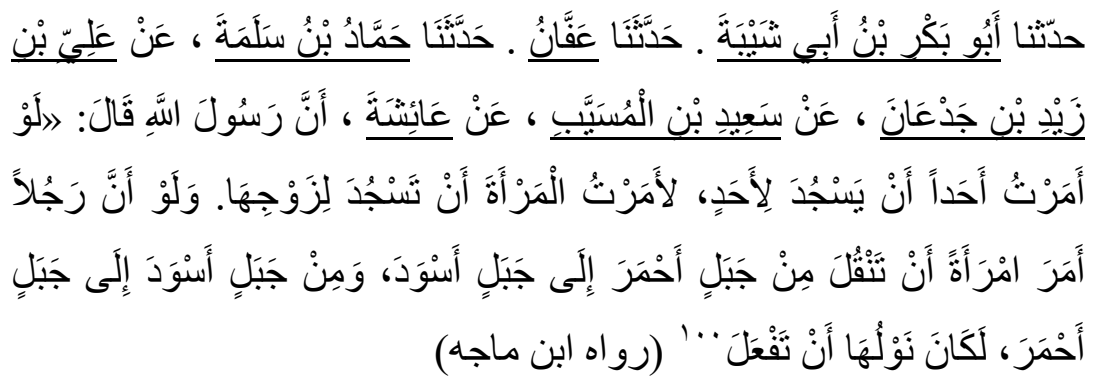

Dalam sanad hadîts ini terdapat seorang rawi yakni 'Alî bin Zaid bin Jad'âni, beragam penilaian terhadap 'Alî bin Zaid bin Jad'âni yakni, laisa bi al-Qawî, 101 dha'îf al-

97 Penilaian ini diberikan oleh Abû Hâtim. Lihat, Jamâl ad-Dîn Ibnu az-Zakî Abî Muhammad al-Qudhâ'î al-Mizzî, Tahdzîb al-Kamâl, (Beirût: Dâr al-Fikr, 1994), Juz, XVI. h. 169

98 Penilaian ini diberikan oleh Ibnu Hâjar mengutip penilaian an-Nasâ'î. Lihat, Abû al-Fadhl Ahmad bin 'Alî bin Muhammad alKunânî al-Asqalânî, Tahdzîb at-Tahdzîb, (Beirût: Dâr al-Ma'rifah, 1996), Juz, IV, h. 595.

99 Kedua tingkatan jarh yang disebutkan yakni Mudhtarib alHadits dan dha'if termasuk dalam lafazh jarh tingkatan kedua, disebabkan kerancuan hafalannya oleh sebab itu hadits ini tidak dapat dijadikan hujjah, namun hadîts ini tetap ditulis sebagai I'tibâr untuk dibandingkan dengan hadîts lain. Lihat, Mahmûd athThahhân, Dasar-dasar Ilmu Takhrij dan Studi Sanad, terj. Agil Husin al-Munawwar, (Semarang: Dina Utama, 1995), h. 151.

100 Ibnu Mâjah, Sunan Ibnu Mâjah, Kitâb an-Nikâh, Bab Hak Suami atas Istri, No. 1906, Juz, I, h. 595.

101 Abû Zur'ah menilainya dengan laisa bi al-Qawîn, lihat, alMizzî, Tahdzîb al-Kamâl, Juz, XIII, h. 269. 
hadits, 102 lâ Yuhtaju bih, ${ }^{103}$ Yang menjadikan hadîts ini dha'îf.

Kedua hadîts yang disebutkan di atas, keduaduanya berstatus hadîts dha'îf, sebab masing-masing hadits hanya memiliki satu jalur periwayatan yang di dalamnya terdapat perawi yang dha'îf jadi dengan ini Khaled mempermasalahkan kedua hadits yang sudah berstatus dha'îf sejak awal. Dan ini merupakan suatu bentuk kekeliruan dari Khaled. Kekeliruan selanjutnya dari Khaled, ia tidak mempertimbangkan salah satu riwayat tentang sujud pada suami yang diriwayatkan Abû Hurairah. Sebab hadîts tersebut memiliki kualitas yang lebih baik dari hadîts-hadits sujud pada suami yang lain (hasan shahîh), serta terhindar dari pengaruh tambahan sujud kepada Nabi yakni keterangan-keterangan bukit, pelana, punggung unta, dan bisul.

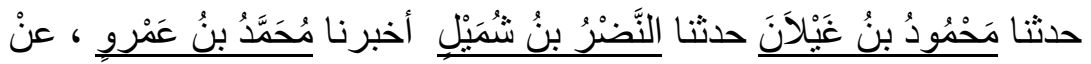

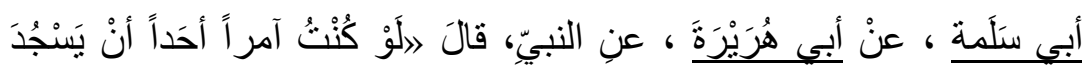

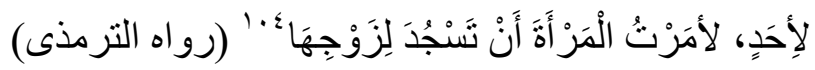

"Menceritakan kepada kami Mahmûd bin Ghaylân, menceritakan kepada kami Nadhr bin Syumail, mengabarkan kepada kami Muhammad bin 'Amr, dari Abî Salamah, dari Abî Hurairah, Nabi Saw bersabda: jika

102 An-Nasâ'î menilainya dengan dha'îf al-hadîts, lihat, al-Mizzî, Tahdzîb al-Kamâl, Juz, XIII, h. 269.

103 Abû hâtim menilainya dengan lâ Yuhtaju bih, lihat, al-Mizzî, Tahdzîb al-Kamâl, Juz, XIII, h. 269.

104 Berkata Abû 'îsa (Tirmidzî): hadîts yang diriwayatkan Abû Hurairah merupakan hadîts hasan Gharîb Shahîh melalui jalur ini, yakni Muhammad bin 'Amr, Abî Salamah, dan Abî Hurairah. atTirmidzî, Sunan at-Tirmidzy, Kitâb ar-Radhâ', Bab Hak-hak Suami atas Istri, No. 1155, Juz, IV, h. 253. Lihat juga dalam kitab syarhnya, Muhammad 'Abd Rahmmân Ibnu 'Abd al-Rahîm al-Mubarakfuri, Tuhfat al-Ahwâdz bi Syarh Jâmi' al-Tirmidzî, h. $27 \overline{1}$. 
M. Rifian Panigoro, MA : Kritik Khaled Abou El-Fadl Atas Epistemologi Hadits Sujud pada Suami

sekiranya aku dapat memerintahkan seseorang untuk sujud kepada seseorang yang lain, akan aku perintahkan istri untuk sujud kepada suaminya".

Berikutnya Khaled mengaitkan kalimat fîhi ghâyat al-mubâlaghah dengan penambahan luar biasa terhadap redaksi hadîts-hadîts sujud pada suami ini. 105 Khaled mengutip ini dari tuhfah al-ahwwâdzi 106 setelah dilihat kembali, kalimat fîhi ghâyat al-mubâlaghah ini tidak ada kaitan sama sekali dengan penambahan luar biasa sebagaimana dimaksud Khaled. Kalimat fîhi ghâyat almubâlaghah digunakan oleh Mubârakfuri untuk mensyarahkan hadîts sujud pada suami dari Abû Hurairah yang diriwayatkan oleh at-Tirmidzî107 pada redaksi لأمرت)

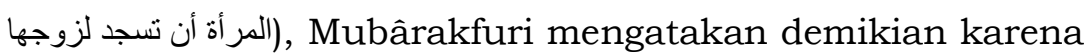
sujud semata-mata hanya untuk Tuhan, tidak dibenarkan sujud kepada manusia. Maka lafazh (لأمرت المرأة أن تسجد لزوجها) merupakan lafazh yang sangat hiperbolis atau fîhi ghâyat al-mubâlaghah.

Dengan penjelasan Mubârakfuri ini maka hadîts sujud pada suami 108 terhindar dari pengaruh teologis sebagaimana yang dikatakan oleh Khaled. Sebab aspek teologis yang dimaksud Khaled ialah adanya persamaan antara Tuhan dan suami. Bersujud kepada selain Tuhan adalah sebuah perbuatan yang dilarang Q.S Âli Imrân 3: 80 .

105 Khaled Abou el-Fadl, Speaking in God's Name,h, 217.

106 Muhammad 'Abd Raḥmân Ibnu 'Abd al-Rahî̀m alMubarakfuri, Tuhfat al-Ahwwâdz bi Syarh Jâmi' al-Tirmidzî, h. 271.

107 at-Tirmidzî, Sunan Tirmidzy, Kitâb ar-Radhâ‘, Bab Hak-hak Suami atas Istri, No. 1155, Juz, IV, h. 253.

108 Abû 'îsa Muhammad bin Surah at-Tirmidzy, (Beirût: Dâr alFikr, 1994), Juz IV, h. 253. 
Dan satu hal yang patut diperhatikan dalam hadits sujud pada suami ini adalah kalimatnya yang menggunakan kata gl yang bermakna seandainya, nabi bersabda jika seandainya aku dapat memerintahkan seseorang untuk sujud kepada seseorang yang lain, maka akan aku perintahkan seorang istri untuk sujud pada suami. Maka praktik sujud dalam hadits ini tidak pernah terjadi sebab Nabi Saw tidak dapat memerintahkan hal tersebut.

d. Memberikan Dampak Sosial

Khaled menyatakan bahwa dampak nyata dari hadîts-hadîts tersebut adalah bahwa seorang istri mempunyai kewajiban yang sangat besar terhadap laki-laki yang menjadi suaminya, semata karena posisi laki-laki tersebut sebagai suaminya. Seorang suami berhak mendapat penghormatan dan pelayanan dari istrinya. 109

Hadîts ini akan terkesan merendahkan perempuan apabila dipahami secara literal. Hadits ini membutuhkan riwayat-riwayat lain untuk menjelaskan makna yang terkandung di dalamnya. ${ }^{110}$ Hadîts sujud pada suami ini termasuk dalam bab hak-hak suami atas istri, sebagaimana telah dijelaskan pada bagian sebelumnya bahwasanya hadits ini merupakan ungkapan majas disebabkan oleh banyaknya hak-hak suami atas istrinya, dan begitu lemahnya syukur seorang istri terhadap hakhak itu. Oleh karena itu hadîts ini menjadi dorongan bagi seorang istri untuk menunaikan kewajibannya terhadap suami.

109 Khaled Abou el-Fadl, Speaking in God's Name,h, 218.

110 Yûsuf al-Qardhâwî, al-Madkhâl li Dirasât as-Sunnah anNabawiyyah, terj, A. Najiyullah, (Jakarta: Islamuna, 1994), h. 153. 
M. Rifian Panigoro, MA : Kritik Khaled Abou El-Fadl Atas Epistemologi Hadits Sujud pada Suami

Dan seorang suami pun tidak terlepas dari menunaikan kewajiban atas istrinya, sebab istri juga memiliki hak atas suami, sebagaimana disebutkan dalam hadîts-hadîts berikut:

"Wahai Rasul apa salah satu hak istri atas suami?, Rasulullah Saw bersabda: Engkau memberinya makan jika engkau makan, engkau memberinya pakaian jika engkau berpakaian, janganlah memukul wajah dan janganlah menjelek-jelekkannya serta janganlah memisahkannya kecuali tetap dalam rumah."111

Rasulullah bersabda:"Jangan kamu lakukan itu, berpuasa dan berbukalah, beribadah dan tidurlah, sesungguhnya bagi tubuhmu ada hak atasmu, bagi dua matamu ada hak atasmu dan bagi isterimu ada hak atasmu " 112

dari Jâbir bin 'Abdillah, bertakwalah kepada Allah tentang wanita, sesungguhnya kalian menikahi mereka dengan lindungan Allah, dan telah dihalalkan bagi kalian kehormatan mereka. dan bagimu hak atas mereka yaitu mereka tidak boleh membiarkan seorangpun yang kalian benci menginjak hamparan kalian (masuk ke dalam rumah). Jika mereka melakukannya, pukullah mereka dengan pukulan yang tidak melukai dan mereka memiliki hak untuk mendapatkan rizki dan pakaian dengan cara ma'ruf." ${ }^{113}$

Dengan adanya riwayat-riwayat ini, maka kesan misoginis yang ditimbulkan oleh hadîts ini dapat dihilangkan. Ketika berbicara tentang hak suami atas istri dikaitkan dengan kurangnya rasa bersyukur istri terhadap

111 Abû Dâwûd, Sunan Abî dâwûd, Kitâb an-Nikâh, Bab Hakhak Istri atas Suami, No. 2146, Juz, VI, h. 180.

112 Al-Bukhârî, Shahîh $\underline{h}$ Bukhârî, Kitâb an-Nikâh, Bab Bagi Istrimu Ada Hak atas Kamu, No. 5199, Juz, V, h. 1995.

113Abû al-Husain Muslim bin al-Hajjâj bin Muslim al-Qusyairi an-Naisabûri, Shahîh Muslim, Kitâb al-Hajj, Bâb Hajjah an-Nabî, (Beirût: Dâr al-Kutub al-Ilmiyah, 1992), No. 2903. Juz, VIII, h. 135. 
suami, ${ }^{114}$ dan sebaliknya, ketika berbicara tentang hak-hak istri atas suami maka dikaitkanlah dengan perintah untuk berperilaku yang baik terhadap istri Q.S. an-Nisâ' 4: 19 .

Ini merupakan sebuah aturan yang benar-benar adil, dan merupakan sebuah keseimbangan dalam rumah tangga dikarenakan sifat dasar dari keduanya yang berbeda. 115 Ini menunjukkan bahwa Islam sama sekali tidak merendahkan derajat perempuan. Suami dan istri masing-masing memiliki kewajiban yang harus ditunaikan dan memiliki hak atas masing-masing. Dan tuntut menuntut hak ini tidak akan terjadi apabila masing-masing dari keduanya menunaikan kewajibannya, karena apa-apa yang menjadi kewajiban istri akan menjadi hak suami dan begitupun sebaliknya.

114al-Bukhârî, Shahîh Bukhârî, Kitâb al-îmân, No. 29, Juz, I, h. 19. Lihat, Muslim, Shahîh Muslim, Kitâb ar-Radhâ', Bâb alWashiyyah bi an-Nisâ', No. 3601, Juz, 10, h. 49.

115 Laki-laki mendapatkan legalitas dari al-Qur'an sebagai qawwâm bagi perempuan, penafsiran mengenai Qowwam ini sangat beragam, Ibnu Jarîr Al-Thabâri menjelaskan maksud "qowwâmûn" adalah penanggung jawab untuk mendidik dan membimbing istri agar mentaati kewajibannya kepada Allah dan suami. lihat, Abû Ja'far Muhammad bin Jarîr ath-Thabarî, Tafsîr ath-Thabarî, (Beirût: Dâr al-Ma'ârif, 1992), Juz, V, h. 37. Dalam tafsir al-kasysyâf, azZamakhsyarî menjelaskan bahwa kaum laki-laki berkewajiban melaksanakan amar ma'rûf nahî munkâr kepada perempuan sebagai mana penguasa pada rakyatnya. Lihat, Abû al-Qâsim Mahmûd bin 'Umar az-Zamakhsyarî, Tafsîr al-Kasysyâf, (Beirût: Dâr al-Fikr, tth), Juz, I, h. 523. Legalitas dari al-Qur'an inilah yang dikhawatirkan terjadi penyelewengan di mana seorang suami akan bertindak semena-mena terhadap perempuan (istrinya). Maka hadits-hadîts tentang kewajiban seorang suami terhadap istri banyak disertai dengan perintah untuk memperlakukan mereka dengan cara yang ma'rûf. 
M. Rifian Panigoro, MA : Kritik Khaled Abou El-Fadl Atas Epistemologi Hadits Sujud pada Suami

\section{PENUTUP}

Dari uraian di atas dapat dilihat bahwa Abou Fadl menawarkan sebuah konsep jeda ketelitian untuk memahami hadist yang berbau misoginis tersebut. Sebab dengan ini akan menggiring manusia untuk tidak menggunakan hadîts-hadîts tentang bersujud dan taat kepada suami sebagai sandaran dalam persoalan hukum atau teologi. Kritikannya selain berdasarkan sanad ia juga sangat terusik bahwa hadist tersebut benar-benar ucapan Nabi.

Kritik Khaled terbagi menjadi 4 garis besar, yaitu: penolakan Khaled terhadap periwayatan Abu Hurairah, tidak sejalan dengan diskursus al-Qur'an, adanya penambahan pada redaksi Hadits dan memberikan dampak sosial bahwa tanggung jawab seorang istri sangatlah besar. Hadist ini jika dipahami secara literer akan memberikan kesan merendahkan perempuan, perlu adanya ayat dan hadist-hadist lain untuk memahami majas anata hak dan kewajiban suami dan istri. Dan sebagaimana mestinya adanya hadist ini seharusnya emmang harus dipahami secara universal dan holistic agar menjadi dorongan bagi seorang istri untuk menunaikan kewajibannya terhadap suami. 


\section{DAFTAR PUSTAKA}

Abû Rayyah, Syaikh al-Mudhirah Abû Hurairah, Mesir: Dâr alMa'ârif, tth.

al-Adlâbi, Shalâh ad-Din bin Ahmad, Minhâj Naqd al-Matan, Beirût: Dâr al-Afâq al-Jadîdah, tth.

al-Asqalânî, Abû al-Fadhl Aḥmad bin 'Alî bin Muhammad alKunânî, Tahdzîb at-Tahdzîb, Beirût: Dâr al-Ma'rifah, 1996.

al-Barr, Abî 'Amr Yûsuf bin 'Abd, Jâmi' bayân 'ilm wa fadhl, Riyâdh: Dâr Ibnu al-Jauzî‘', 1994.

al-Bukhârî, Abû 'Abdillah Muhammad bin Ismâ'il bin Ibrâhîm bin Mughîrah, Shahih Bukharî, Kitâb al-Buyû', Bab Tentang Firman Allah Ta'alâ, Tt: dâr Ibnu Katsîr, 1992

al-Damasyqî, Abû al-Fidâ Ismâ'il Ibnu Katsîr al-Qurâsî, Tafsîr Ibnu Katsîr, Beirut: Dâr ihyâ al-Turâts al-Arabî, 1985.

al-Khatîb, Muhammad 'ajjâ, j as-Sunnah Qabla at-tadwîn, Kairo: Ummul Qurâ li at-Thabâ'ah wa an-Nasyr, 1988.

al-Mizzî, Jamâl ad-Dîn Ibnu az-Zakî Abî Muhammad al-Qudhâ‘̂̂, Tahdzîb al-Kamâl, Beirût: Dâr al-Fikr, 1994.

al-Mubarakfuri, Muhammad 'Abd Raḩmân Ibnu 'Abd al-Rahîm,

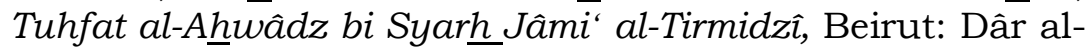
Kutub al-Ilmiyyah, tth

al-Mubarakfuri, Muhammad 'Abd Rahmân Ibnu 'Abd al-Rahîm, Tuhfat al-Ahwwâdz bi Syarh Jâmi' al-Tirmidzî (Beirut: Dâr alKutub al-Ilmiyyah, tth), h. 323.

al-Mubârakfuri, Shafiyyurahmân, ar-Rahîq al-Makhtûm, terj. Agus Suwandi, Jakarta: Ummul Qura, 2012.

al-Mundzirî, Abd al-'Âzhim bin Abd al-Qâwî, al-Targhîb wa alTarhîb, Riyâdh: Maktabah al-Ma'rif li an-Nasyr wa at-Tauzî' $1424 \mathrm{H}$.

al-Musâwî, Syaraf ad-dîn, Menggugat Abû Hurairah: Menelusuri Jejak Langkah dan hadist-hadistnya, Terj. Mustofa Budi Santoso. Jakarta: Pustaka Zahra, 2002. 
M. Rifian Panigoro, MA : Kritik Khaled Abou El-Fadl Atas Epistemologi Hadits Sujud pada Suami

al-Qardhâwî, Yûsuf, al-Madkhâl li Dirasât as-Sunnah anNabawiyyah, terj, A. Najiyullah, Jakarta: Islamuna, 1994.

al-Qardhâwî, Yûsuf, Kaifa Nata'âmal as-sunnah am-Nabawiyyah, Dâr al-Wafâ' li at-Thabâ'ah wa an-Nasyr wa at-Tauzî', 1993.

al-Qutaibah, Muhammad Abdullah bin Muslim, Ta'wîl Mukhtalif Hadits, Beirut: Maktabah al-Islamî, 1999.

al-Tirmidzî, Abû 'îsâ Muhammad bin Sûrah, Sunan Tirmidzy. Beirût: Dâr al-Fikr, 1994.

Amin, Ahmad, Dhuhâ al-Islâm, Mesir: Maktabah an-Nahdhat alMishriyyah, 1936.

an-Naisâbûrî, Abû al-Husain Muslim bin al-Hajjâj bin Muslim alQusyairi, Shahîh Muslim, Beirût: Dâr al-Kutub al-Ilmiyah, 1992.

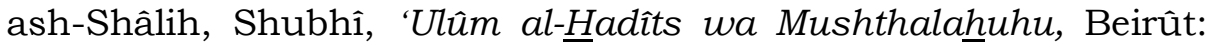
Dâr al-'Ilm li al-Malâyîn, 1984.

as-Samarqandi, Abû Muhammad Abdillâh bin Abdirrahmân bin Fadhil bin Bahram al-Tamîmî al-Dârimî, Sunan al-Dârimi, Beirût: Dâr al-Kutub al-Ilmiyah, 1996.

as-Sijistânî, Abû Dâwûd Sulaimân bin al-'asy'ats bin Ishâq bin Basyîr al-Azdî, Sunan Abî Dâwûd, Beirût: Dâr Ihyâ' atTurâts al-‘Arabî.

asy-Syâfi'î, Muhammad bin Idrîs, ar-Risâlah, Beirût: Dâr al-Kutub al-Ilmiyyah, tth.

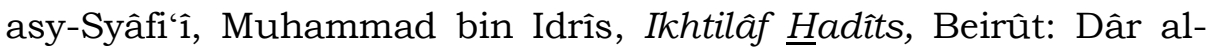
Kutub al-Ilmiyyah, 1986.

asy-Syaibânî, Abû Abdillâh Ahmad bin Muhammad bin Hanbâl, Musnad Imam Ahmad, No. 19039, Juz, V, h. 515.

ath-Thahhân, Maḩmûd, Dasar-dasar Ilmu Takhrij dan Studi Sanad, terj. Agil Husin al-Munawwar, Semarang: Dina Utama, 1995. 
az-Zamakhsyarî, Abû al-Qâsim Mahmû̂d bin 'Umar, Tafsîr alKasysyâf, Beirût: Dâr al-Fikr, tth.

el-Fadl, Khaled Abou, Atas Nama Tuhan; Dari Fikih Otoriter ke Fikih Otoritatif. Terj, Cecep Lukman Yasin, Jakarta: Serambi, 2004.

el-Fadl, Khaled, Abou Speaking in God's Name, Oxford: Oneworld Publications, 2001.

Ibnu Mâjah, Abû 'Abdillah Muhammad bin Yazîd ar-Rab'î alQuzwainî, Sunan Ibnu Mâjah, Beirût: Dâr ihyâ' at-Turâts al'Arabî, tth.

Ismail, Syuhudi, Kaedah Kesahihan Sanad Hadis, Telaah Kritis dan Tinjauan dengan Pendekatann Ilmu Sejarah, Bandung: Bulan Bintang, 1995.

Muhammad 'Abdullah bin Muslim al-Qutaibah, Ta'wîl Mukhtalif Hadits, Beirut: Maktabah al-Islamî, 1999.

Nasrullah, hermeneutika otoritatif khaled m. Abou el fadl: metode kritik atas penafsiran otoritarianisme dalam pemikiran islam, Jurnal Hunafa Vol. 5, No. 2, Agustus 2008.

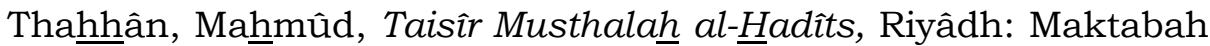
al-Ma'ârif li an-Nasyr wa at-Tauzî', 2004.

Yaqub, Ali Mustafa, Kritik Hadits, Jakarta: Pustaka Firdaus, 2008.

Yuslem, Nawer, 'Ulumul hadits, Jakarta: Mutiara Sumber Widya, 1988. 
M. Rifian Panigoro, MA : Kritik Khaled Abou El-Fadl Atas Epistemologi Hadits Sujud pada Suami 